\title{
THE ROLE OF INTERACTIONS BETWEEN BRAIN NEUROTRANSMITTERS IN PATHOPHYSIOLOGY AND TREATMENT OF AFFECTIVE DISORDERS
}

\author{
E. Dremencov, eliyahu.dremencov@savba.sk \\ Institute of Molecular Physiology and Genetics, Slovak Academy of Sciences, Bratislava, Slovakia; \\ Institute of Experimental Endocrinology, Biomedical Research Center, Slovak Academy of Science, \\ Bratislava, Slovakia; \\ Neuroken Consulting, Groningen, the Netherlands
}

\begin{abstract}
Aim of the review is to summarize the contemporary evidences on interactions between brain neurotransmitters and their role in pathophysiology and treatment of depression. Introduction. Brain neurotransmitters are biological molecules responsible for signal transduction between the neurons. Mammalian brain neurotransmitters belong to the different types of biological molecules, such as amino acids (glutamate and $\gamma$-aminobutyric acid, or GABA), monoamines (serotonin (5-HT), norepinephrine (NE), dopamine (DA), and histamine (HA)), neuropeptides ( $\beta$-endorphin, neurokinin, vasopressin, and oxytocin), or nucleotides (adenosine). Materials and Methods. The author analyzes research papers dedicated to neurotransmitters and their functions in mood regulation and published between 1953 and 2014. The paper focuses on evaluation of data on mechanisms of interactions between different neurotransmitters and their role in development and treatment of certain mental disorders. Results. It has been reported that different neurotransmitters, often belonging to the different types of biological molecules, interact on behavioral, functional, system and molecular levels. These interactions play an important role in pathophysiology of brain diseases, particularly, depression and stress and anxiety-related disorders. Conclusion. Literally all existing antidepressant drugs act on monoamine systems of the brain (5-HT, NE, and DA). Although the last-generation antidepressants and mood stabilizers demonstrated higher safety and efficacy, their therapeutic potential remains limited. The brain adenosine neurotransmission is also a potential target for the future antidepressant, mood stabilizing and antipsychotic drugs. However, these drugs may have severe side effects, for example, on cardiac activity. It is necessary to perform further research and clinical trials to find a solution to the existing difficulties.
\end{abstract}

Keywords: serotonin (5-HT), norepinephrine, dopamine, glutamate, GABA, neuropeptides, hypothalamus, hippocampus, voltage-dependent calcium channels.

\section{Introduction}

Neural system uses two basic mechanisms of information processing. Within neurons, information is processed via passive (synaptic potential) or active (action potential) flow of the electrical signal. Between the neurons, information is exchanged by chemical mediators, called neurotransmitters. Different type of biological molecules act as neurotransmitters, such as amino acids (glutamate and $\gamma$-aminobutyric acid, or GABA), monoamines (serotonin or 5-HT, norepinephrine or NE, dopamine or DA, and histamine or HA) small peptides (so-called neuropeptides, such as encephalin, $\beta$-endorphin), nucleosides (e.g., adenosine), and small organic (such as the ester acetylcholine) and even inorganic molecules (such as nitric oxide or NO) [29].
Some neurotransmitters are specific for central neuronal system (CNS), such as neuropeptides, glutamate and GABA. Others act in both CNS and periphery, such as acetylcholine and monoamines. The majority of neurons projecting from one area of the CNS to another (e.g., between brain hemispheres or between midbrain and cerebral cortex) are secreting glutamate or GABA (Fig. 1). Thus, these two neurotransmitters play a primary role in neuronal functions involving distant exchange of information, such as sensory and motor functions. It is notable that the distantly-projecting cortical usually neurons release glutamate, while midbrain (thalamic and striatal) cells secret GABA. The locally-projecting CNS interneurons express GABA (e.g., cortical interneurons) or acetylcholine (some striatal interneurons). 


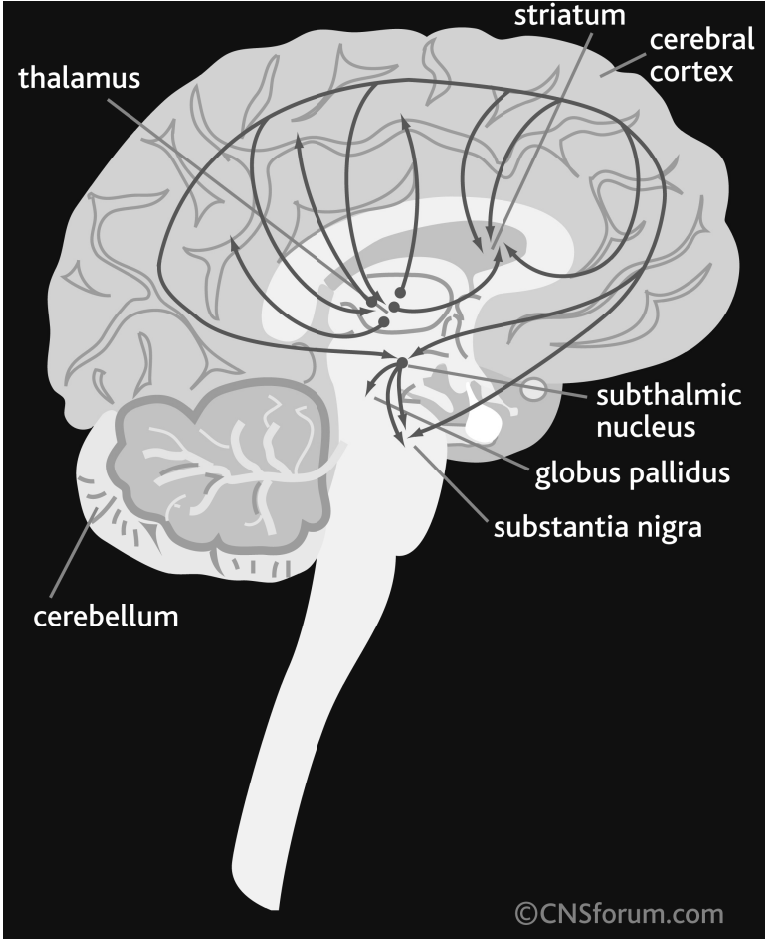

A

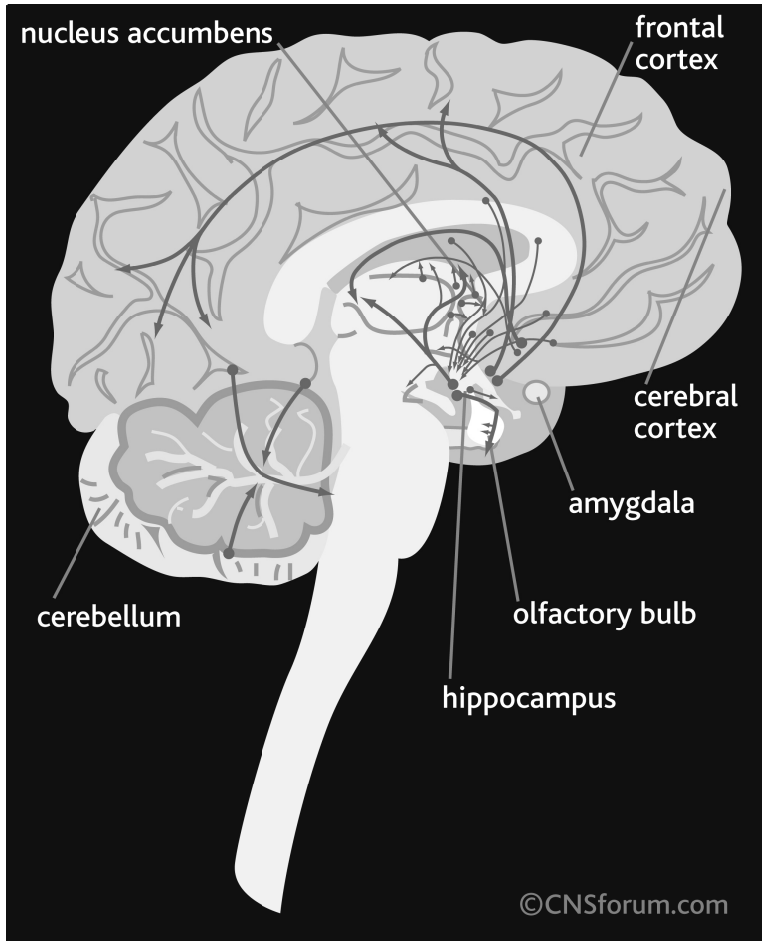

Fig. 1. Glutamate and $y$-aminobutyric acid (GABA) pathways of human brain: Glutamate pathways (A); GABA pathways (B). From CNS Forum (www.cnsforum.com); published with the permission of Lundbeck Institute, Valby, Denmark

Neuronal systems expressing monoamines and neuropeptides have different functional anatomy (Fig. 2), suggesting a unique biological function. For several reasons will be explained below, these neurotransmitters are considered as a primary target for the treatment of mood disorders.

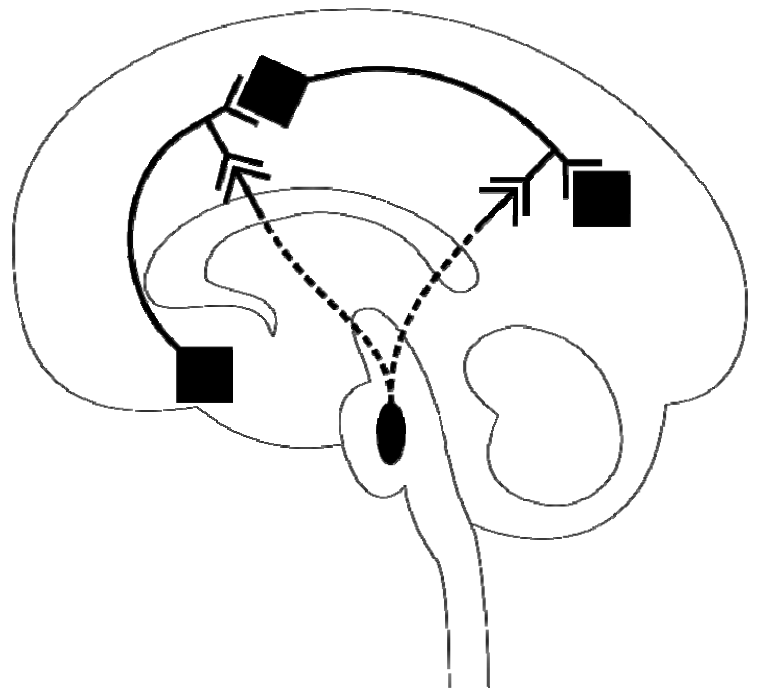

Fig. 2. Serotonin (5-HT), norepinephrine (NE), and dopamine (SA) pathways of human brain. From CNS Forum (www.cnsforum.com); published with the permission of Lundbeck Institute, Valby, Denmark

\section{Role of monoamines in the regulation of the mood}

The catecholamines dopamine and norepinephrine and indolamine serotonin (or 5-HT) are traditionally referred to as monoamines. Monoamines share several features, such as chemical structure, metabolism, and functional organization of monoamine-secreting neurons.

Monoamine systems share similar neuroanatomy. The cell bodies of monoamine-secreting neurons are located in one or several closely located brain midbrain areas and their axons innervate distant areas of the CNS, such as cerebral cortex, basal ganglia, cerebellum, brain stem and spinal cord (Figs. 2 and 3). The majority of projections of monoamine-secreting neurons innervate limbic areas of the brain, such as hippocampus, amygdala, nucleus accumbens, and prefrontal cortex $[17,20,22]$. These special neuroanatomical features of monoamine-secreting neurons suggest that they play a unique role in the CNS. While amino acid (glutamate and GABA) secreting neurons are responsible for the flow of information from one brain area to another, monoamine neurons modulate information flow and processing across the CNS. This feature, together with the fact that the higher density of axons of 
Receptors to monoamines

\begin{tabular}{|l|c|c|c|}
\hline & Serotonin $(5-\mathrm{HT})$ Receptors & $\begin{array}{c}\text { Norepinephrine (NE) } \\
\text { Receptors }\end{array}$ & $\begin{array}{c}\text { Dopamine (DA) } \\
\text { Receptors }\end{array}$ \\
\hline $\mathrm{G}_{\mathrm{I} / \mathrm{O}}$-Coupled & $5-\mathrm{HT}_{1 \mathrm{~A}}, 5-\mathrm{HT}_{1 \mathrm{~B}}, 5-\mathrm{HT}_{5}$ & $\alpha_{1}$-adrenergic & $\begin{array}{c}\mathrm{D}_{2} \text {-like receptors } \\
\left(\mathrm{D}_{1}, \mathrm{D}_{4}\right)\end{array}$ \\
\hline $\mathrm{G}_{\mathrm{S}}$-Coupled & $5-\mathrm{HT}_{2 \mathrm{~A}}, 5-\mathrm{HT}_{2 \mathrm{~B}}, 5-\mathrm{HT}_{2 \mathrm{C}}$ & $\beta$-adrenergic & $\begin{array}{c}\mathrm{D}_{2} \text {-like receptors } \\
\left(\mathrm{D}_{2}, \mathrm{D}_{3}, \mathrm{D}_{5}\right)\end{array}$ \\
\hline $\mathrm{G}_{\mathrm{Q} / \mathrm{Z} \text {-Coupled }}$ & $5-\mathrm{HT}_{4}, 5-\mathrm{HT}_{6}, 5-\mathrm{HT}_{7}$ & $\alpha_{2}$-adrenergic & \\
\hline Other & $5-\mathrm{HT}_{3}$ (super-family-coupled to $\mathrm{K}^{+}$channels) & & \\
\hline
\end{tabular}

monoamine-secreting neurons arrive to the limbic system, suggest that brain monoamines play a primary role in memory, learning, cognition, and emotional processing.

Almost all receptors to monoamines are G-protein coupled (Table 1), with the only known exception is "superfamily" ion-channel coupled $5-\mathrm{HT}_{3}$ serotonin receptors. There are one or two receptor in each monoamine system which are acting as autoreceptor. All known autoreceptors are coupled to $\mathrm{G}_{\mathrm{I}}$ proteins. Activation of these receptors usually leads to the opening of secondmessenger-mediated ion channels (such as $\mathrm{G}_{\mathrm{I} \beta \gamma^{-}}$ dependent $\mathrm{K}^{+}$channels) and to the hyperpolarization of cell membrane.

There are four sources of evidence on the role of monoamines in mood regulation. The first is depletion studies in humans, meaning artificial reduction of biosynthesis of specific monoamine, e.g., by specific diet lacking precursor for this transmitter. For instance, reserpine, a blocker of vesicular monoamine transporter, can induce depressive symptoms. Down-regulation of 5-HT system by the dietary depletion of its precursor tryptophan results in rapid relapse of depression in successfully treated patients. Partial relapse on depressive symptoms was also observed after catecholamine depletion [14]. Second source of evidences is clinical observations of the effects of antidepressant drugs. This topic will be elaborated in depth in the next paragraph.

Third source of evidences is neuroimaging studies in animals or human subjects. The advanced imaging techniques, such as positron emission tomography (PET), allow quantitative detection of levels of specific neurotransmitters, using radioactive-labeled ligands to the receptors (usually autoreceptors) of this transmitter.

The forth source of evidence are behavior and in vivo studies in laboratory animals, and especially combination of these methods. Behavior neuroscience techniques are used to investigate the effects of psychoactive compounds on certain behavior characteristics of laboratory animals, such as motivation, reward, cognition, anxiety, and exploratory behavior. In vivo microdialysis and electrophysiology are used to study the effects of CNS drugs on the release of neurotransmitters and electrical activity of neurons (synaptic and action potentials, respectively).

3. Development of the antidepressant drugs: from multiple-target medicines to highly-selective medicines and back to multiple-target drugs

The first antidepressant drug, isoniasid, was coincidentally discovered in 1953, when the aim was to develop new anti-tuberculosis medication [4]. It was suggested that the antidepressant effect of isoniaside could be explained by its ability to inhibit monoamine oxidase (MAO), an enzyme metabolizing serotonin (5-HT), norepinephrine (NE) and dopamine (DA). It was therefore hypothesized that depression and affective disorders result from reduced transmission within 5-HT, NE and/or DA systems [13,39].

Based on this hypothesis, two first families of antidepressant drugs were developed. They are MAO inhibitors (like the above-mentioned isoniasid) and tricyclic antidepressants (TCAs). MAO inhibitors increase 5-HT, NE and DA availability by suppressing their metabolism $[6,7]$. TCAs stimulate monoamine tone by inhibiting the reuptake of 5-HT, NE and/or DA [10,35].

Further research and development of antidepressant medications have been motivated by two main goals: reducing toxicity and side effects of the drugs and improving their clinical efficacy. The first attempt to increase clinical efficacy of antidepressant drugs was to increase their selectivity to the NE system. NE transmission is causally related to fear, stress and anxiety. The NE system was therefore suggested to play a central role in mood and affective disorders. Indeed, the selective NE reuptake inhibitors that were developed demonstrated effectiveness in the treatment of depression. However, it was sug- 
gested that the antidepressant effect of NE reuptake inhibitors is mediated by their indirect stimulatory effect on the 5-HT system rather than by their direct effect on the NE system. Thus, depressive symptoms return when 5-HT, but not $\mathrm{NE}$ depletion is following the treatment with NE reuptake inhibitors [14]. Moreover, all antidepressants, including selective NE reuptake inhibitors, stimulate 5-HT transmission, whereas some antidepressants suppress NE transmission [19, 20,30].

It is well established today that the main therapeutic effects of antidepressants is explained by their ability to stimulate 5 -HT transmission, either directly or non-directly. As a result, SSRIs are used as a first-line treatment in depression. However, the clinical efficacy of SSRIs is still limited. The major limitations are the lack of adequate response to the treatment (estimated to be at approximately $30 \%$ ), risk of post-treatment relapse of the disease $(\sim 30 \%)$ and delay between beginning of the treatment and the onset of the first clinical effect (2-3 weeks) [31,38].

Depression is characterized by multiple cognitive, emotional and physical symptoms. It is therefore likely that several different neuronal systems and transmitters are involved in the pathophysiology of the disease. For example, an abnormality in DA and endorphin transmission might be relevant to anhedonia, NE to fatigue and anxiety, histamine and acetylcholine to cognitive disturbances. Most neurotransmitter systems in the brain are auto-regulated and crossregulated by other systems. Antidepressant medications that directly modulate one system will indirectly affect others as well. For example, since 5-HT inhibits NE and DA neuronal firing activity, SSRIs stimulate 5-HT transmission directly and might suppress NE and DA tone indirectly. The lack of adequate treatment response observed in some patients might actually be explained by this inhibition of catecholamine neurotransmission $[15,16]$.

\section{Histamine, a forgotten monoamine}

Histamine (HA) is a monoamine synthesized from the amino acid histidine. Histamine is primary known as an important mediator of the immune system. However, it is also acting as a CNS neurotransmitter.

It was discussed in the previous paragraphs that the functional interactions between 5-HT, norepinephrine NE and dopamine DA systems play an important role in the response to antidepressant and antipsychotic treatments $[18,22,23$,
$24,25]$. The interaction HA and other monoamines (5-HT, NE, and DA) received, however, lesser attention.

The neuroanatomy of brain HA system is similar to other monoamine systems. The cell bodies of HA neurons are located in the tuberomammillary nucleus (TMN) of the hypothalamus. Their projections innervate different areas of midbrain and telencephalon, including the dorsal raphe nucleus (DRN), locus coeruleus (LC) and ventral regimental area (VTA), the brain areas consist of cell bodies of 5-HT, NE and DA neurons, respectively $[1,2,3,28,33,36,43]$. This suggests that HA functionally interacts with 5-HT, NE, and DA systems.

There are four HA receptors: $\mathrm{H}_{1}-\mathrm{H}_{4}[5,8,26$, 32]. Histamine- $1, \mathrm{H}_{2}$, and $\mathrm{H}_{2}$ receptors are expressed both in the immune system and in the brain [9]. The $\mathrm{H}_{3}$ receptors are expressed nearly exclusive in the CNS. They are widely distributed across the brain; the highest density of $\mathrm{H}_{3}$ receptors has been observed in the striatum, hippocampus and cerebral cortex [1, 34, 37]. Histamine-1 receptors are $\mathrm{G}_{\mathrm{Q}}, \mathrm{H}_{2}-\mathrm{G}_{\mathrm{S}}$ and $\mathrm{H}_{3}$ and $\mathrm{H}_{4}$ $\mathrm{G}_{\mathrm{I} / \mathrm{O}}$ protein-coupled. The activation of $\mathrm{H}_{1}$ and $\mathrm{H}_{2}$ receptors leads to neuronal excitation and $\mathrm{H}_{3}$ to inhibition [41, 42]. Histamine-3 receptors are only inhibitory histamine receptors widely and densely expressed in the brain, on both nerve terminals of histamine neurons and on postsynaptic cells [26].

It has been previously reported that $\mathrm{H}_{3}$ receptors play an important role in the regulation of brain HA system. Thioperamide, an inverse agonist of $\mathrm{H}_{3} / \mathrm{H}_{4}$ receptors [27], increased extracellular HA levels in the TMN and prefrontal cortex (PFC). Systemic administration $(1 \mathrm{mg} / \mathrm{kg}$, s.c.) of the selective agonist of $\mathrm{H}_{3}$ receptors, immepip dihydrochloride [44], decreased HA concentrations in the TMN and PFC. Local intraPFC perfusion of thioperamide increased, and of immepip decreased extracellular HA in both TMN and PFC. Local intra-TMN perfusion of thioperamide or immepip decreased HA levels in the TMN, but in the PFC. It was therefore concluded that cortical $\mathrm{H}_{3}$ receptors negatively regulate HA neurotransmission, possibly through the inhibition of excitatory cortical neurons projecting into the TMN.

It was recently observed that the systemic administration of the inverse agonist of $\mathrm{H}_{3} / \mathrm{H}_{4}$ receptors, thioperamide, stimulate $5-\mathrm{HT}, \mathrm{NE}$, and DA release in the prefrontal cortex (PFC). Thioperamide stimulate the firing activity of DA 


\section{Клиническая и экспериментальная медицина}

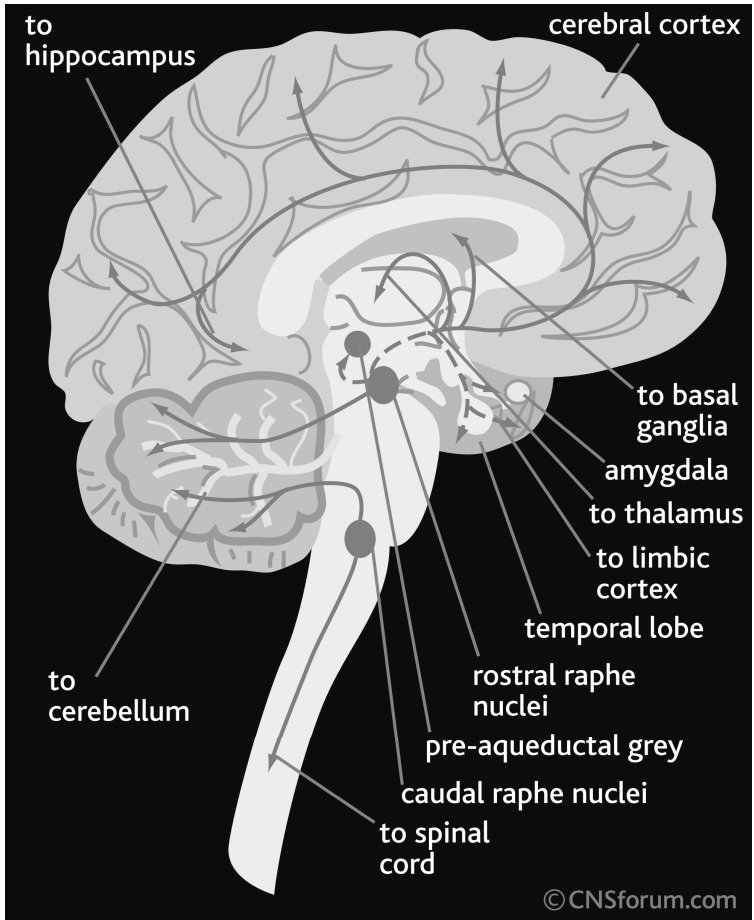

A

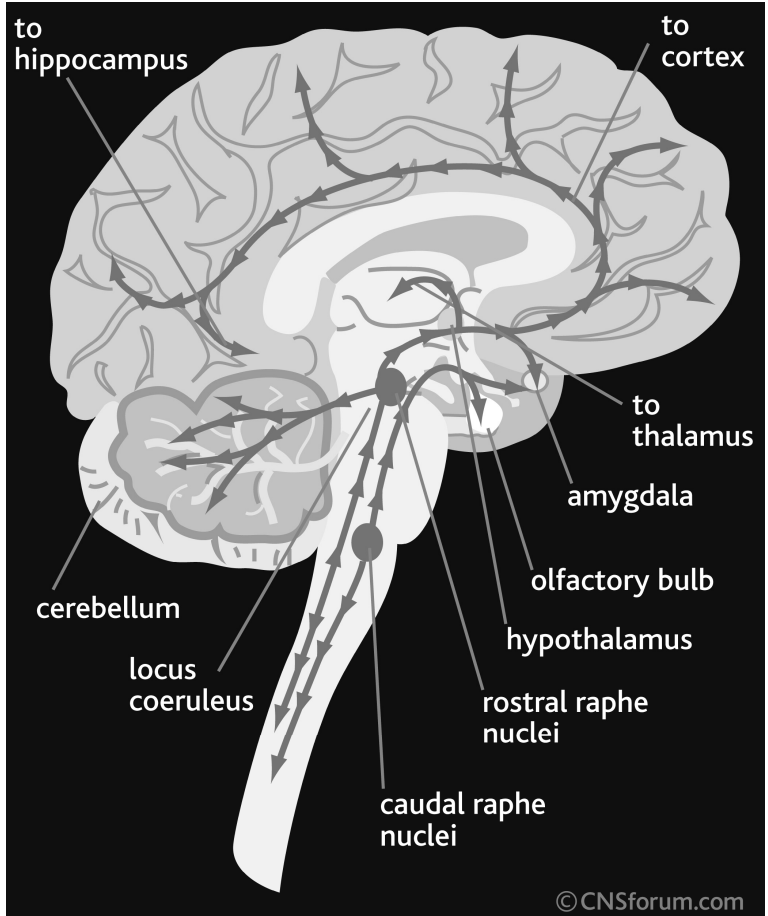

B

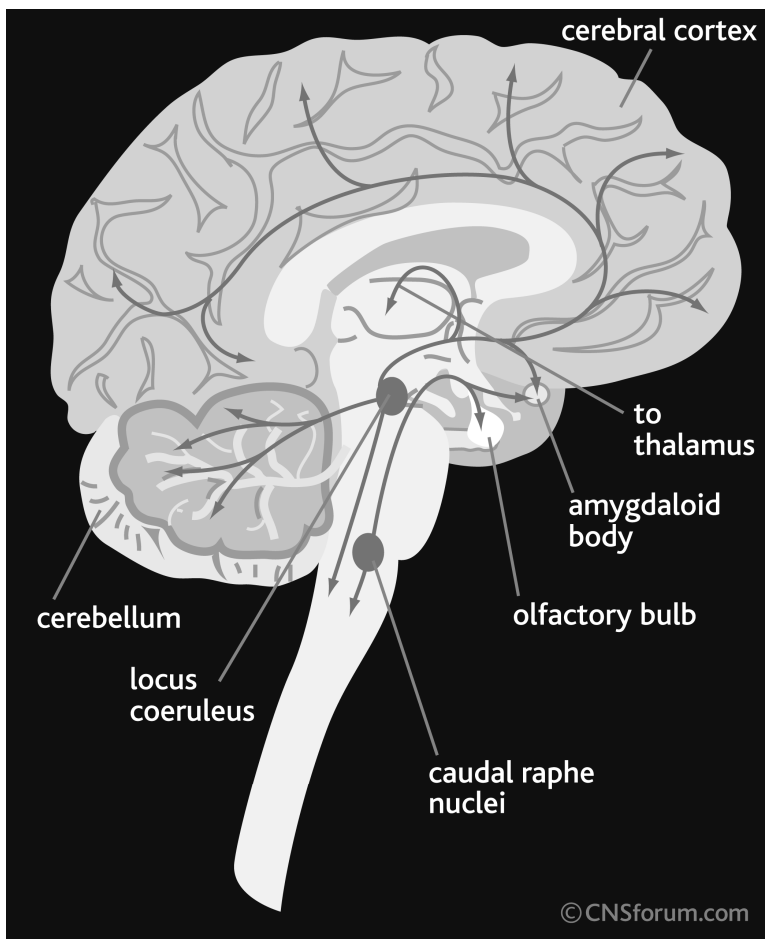

C

Fig. 3. The difference between neuromodulators and other brain neurotransmitters: Serotonin pathways (A); Norepinephrine pathways (B); Dopamine pathways (C). "Regular" neurotransmitters, such as glutamate and GABA, perform the flow of neural information from one brain area to another. The cell bodies of glutamate and GABAsecreting neurons (shown with black rhombs) are distributed across the whole brain. Neuromodulators, however, modulate the flow of neural information across of the brain. The cell bodies of neuromodulatory neurons (shown with black oval) are concentrated in one brain area (raphe nuclei for serotonin, locus coeruleus for norepinephrine, ventral tegmental area and substantia nigra for dopamine, and tuberomammillary nucleus for histamine), and their axons innervate distant areas of the brain 
neurons in the VTA, and immepip reversed the stimulatory effect of thioepramide on DA neuronal activity. Direct local iotophoretic application of HA into the VTA mimicked the effect of systemic administration of thioperamide, suggesting that the effect of thioperamide is mediated via the activation of brain HA release (and subsequent activation of $\mathrm{H}_{1}$ receptors in the VTA) rather than via direct effect of thioperamide on VTA $\mathrm{H}_{3}$ receptors (Fig. 3).

\section{Role of brain amino acids (glutamate and GABA) and autoregulation of monoaminergic systems and interactions between them}

Brain monoamine systems are auto-regulated and interact each another either directly (monosynaptically) or via polysynaptic loops, involving glutamate and GABA neurons. Thus, an increase in 5-HT or HA levels in the PFC leads to the activation of inhibitory $5-\mathrm{HT}_{1 \mathrm{~A}}$ or $\mathrm{H}_{3}$ receptors on cortical neurons projecting to the DRN and TMN, respectively. Serotonin-2A receptors activate GABA neurons projecting into the $L C$. This pathway plays a central role in 5-HT-NE interactions $[15,19]$. Finally, the activation of $5-\mathrm{HT}_{2 \mathrm{C}}$ receptors, expressed on the GABA neurons projecting into the DRN and VTA, play an important role in autoregulation of 5-HT system and in 5-HT-DA interactions, respectively $[11,12,18]$.

The DRN-projecting GABA neurons, activated by $5-\mathrm{HT}_{2 \mathrm{C}}$ receptors, on their torn, inhibit 5-HT neurons via GABAB receptors. It is suggesting that some antagonists of GABAB receptors might be used in the treatment of depression and anxiety disorders $[11,12]$.

6. Nucleotide adenosine, the most prevalent and the less studied neurotransmitter

Adenosine is a purine nucleoside playing an important role in numerous biological functions, such as storage and translation of genetic information (as a part of DNA and RNA), metabolism and energy accumulation (within ATP and NADH), and signal transduction (within the second messenger molecules such as cAMP.

In neurons, adenosine aggregated within the synaptic vesicles as a product of metabolism of ATP, which is required for the active transport of the molecules of neurotransmitters into the vesicles. Adenosine aggregated within the synaptic vesicles is co-released together with the primary neurotransmitter into the synaptic shelf and activate specific receptors on the post-synaptic neurons. Thus, adenosine can be considered as one of the most universal and prevalent brain transmitter. However, the neuronal adenosine and its interactions with other neurotransmitters are poorly understood. It is possible that CNS adenosine interact with monoamine systems, suggesting that this transmitter can be involved in pathophysiology and treatment of mood disorders, as will be described in the next paragraph.

\section{Interaction between different} neurotransmitters, acting via different G-protein coupled receptors, on intracellular signal transduction level

It has been observed that some $\mathrm{G}_{\mathrm{S}}$-coupled receptors, such as $D_{1}$ and $A_{2 A}$, interact with $G_{I^{-}}$ coupled receptors, such as $D_{2}$ and $A_{1}$, by forming a $\mathrm{G}_{\mathrm{Q}}$-protein coupled dimmer (Fig. 4). Thus, dimmerization of these receptors, which occurs in the CNS under certain condition, leads to the activation of different pathways of intracellular signal transduction: activation of phosholypase $\mathrm{C}$ (PLC) instead of activation or inhibition of adenylate cyclase (AC).

The recent studies suggest that this molecular interaction has an clinically-important functional output. Thus, an antagonist of adenosine $A_{2 A}$ receptors, $Z M$ 241385, potentiates the $D_{2}$ antagonist haloperidol-induced increase in DA and NE levels in the nucleus accumbens (NAcc) and $\mathrm{PFC}$, respectively. This may explain the beneficial role of some $\mathrm{A}_{2 \mathrm{~A}}$ antagonists in reduction of the side effect of classical antipsychotic drugs (such as catalepsy) and enhancing of their clinical effect on negative and cognitive symptoms of schizophrenia [1]. It is also possible that the $G_{S}$-coupled $A_{2 A}$ receptors also interact with other than $\mathrm{D}_{2} \mathrm{G}_{\mathrm{I}} / \mathrm{G}_{\mathrm{O}}$-coupled monoamine receptors, such as $\alpha_{2}$-adrenergic and $5-\mathrm{HT}_{1 \mathrm{~A} / 1 \mathrm{~B}}$ serotonin receptors. It is making $A_{2 A}$ receptor-making agents potential adjuncts to antidepressant and anxiolytic drugs.

Furthermore, NE plays an important role in the feeling of energy and modulation of feeding behavior. On the other side, adenosine levels correspond to the actual energetic level of the organism. In high energy levels, ATP metabolism is usually stops at ADP level, when in the lowenergy situations ADP can further metabolite into the AMP and/or adenosine (Berg et al., 2002). Adenosine-norepinephrine interactions may, therefore, mediate the cross-talk between the energetic level and feeling of energy and to adapt the feeding behavior to the real energetic needs. 

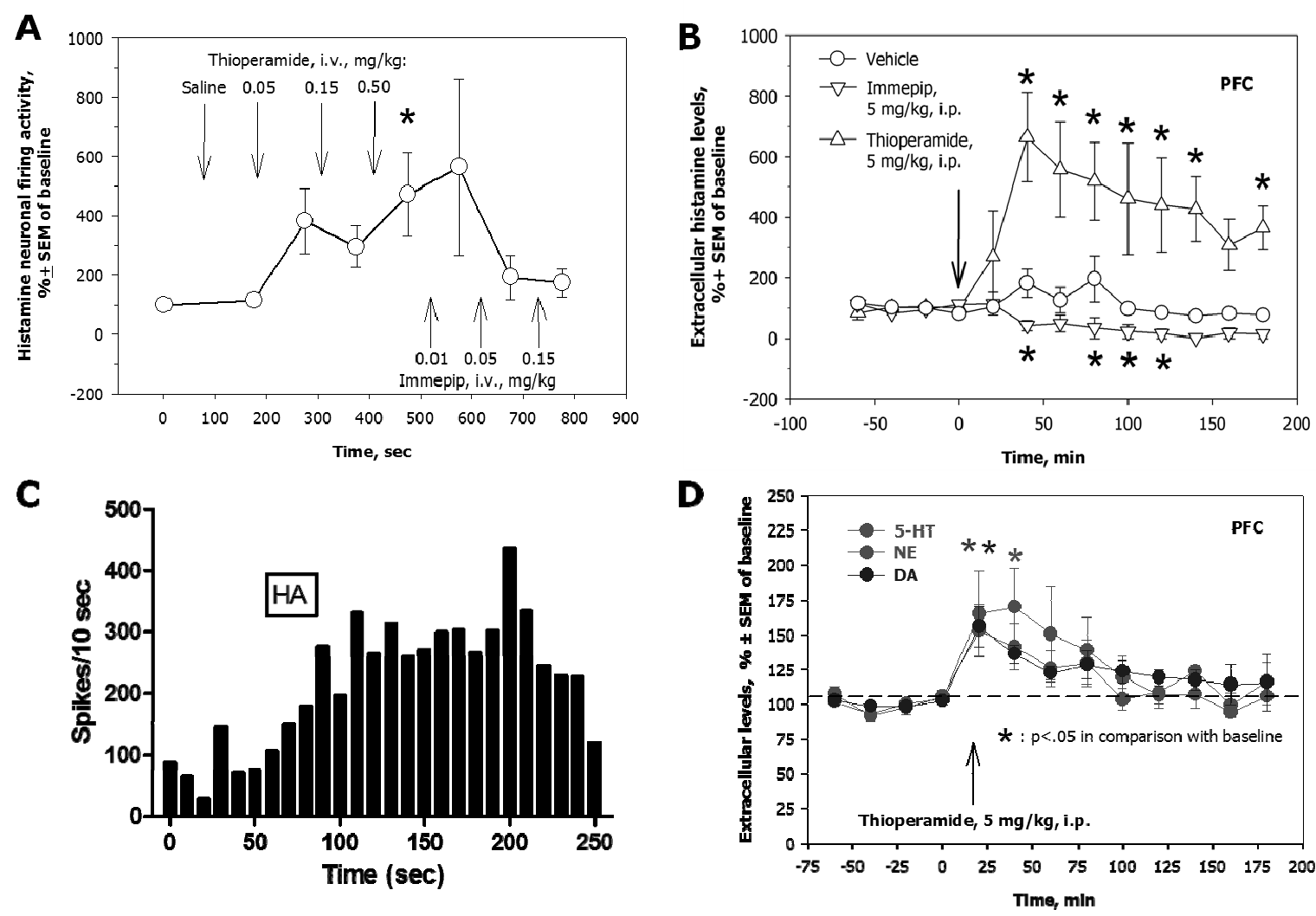

Fig. 4. Autoregulation of brain histamine system and interactions between histamine and other monoamines of the brain. The reverse agonist of histamine-3 and histamine- 4 receptors, thioperamide, and the selective agonist of histamine-3 receptors, immepip, oppositely regulate the firing activity of histamine-secreting neurons of the rat tuberomammillary nucleus in a dose-dependent mater (A); immepip increases, and thioperamide decreases, extracellular levels of histamine in the rat prefrontal cortex (PFC, B); local iontophoretic administration of histamine into the rat ventral tegmental area activates the firing activity of dopamine-secreting neurons (C); systemic administration of thioperamide increases serotonin, norepinephrine, and dopamine levels in the rat prefrontal cortex (PFC, D)

\section{Neuropeptides of the hypothalamus and their role in pathophysiology and treatment of mood disorders}

Oxytocin (OXT) and arginine (AVP) vasopressin are two related neuropeptides, acting as peripheral hormones and CNS neurotransmitters. The majority of OXT and AVP secreting neurons are located in the paraventricular (PVN) and supraoptic (SON) nuclei of the hypothalamus. The axons of the OXT and AVP-secreting neurons located in the SON projecting into the pituitary. OXT and AVP secreted in the SON are released into the blood circulation and act as peripheral hormones. OXT stimulate the uterus contractions during the labor and subsequent milk secretion. AVP is responsible for the water and electrolyte balance.

The axons of OXT and AVP-secreting neurons located in the PVN project into the pituitary, as well as into other brain areas, such as hippocampus, medial amygdala, VTA, substantia nigra, olfactory bulbs and medial preoptic and medial basal areas of the hypothalamus, bed nucleus of stria terminalis, and septum.So far, one type of OXT (OXTR) and two subtypes of AVP $\left(\mathrm{V}_{1 \mathrm{~A}}\right.$ and $\left.\mathrm{V}_{1 \mathrm{~B}}\right)$ have been identified in the CNS. The OXTR and $\mathrm{V}_{1 \mathrm{~A}}$ and $\mathrm{V}_{1 \mathrm{~B}}$ are $\mathrm{G}_{\alpha \mathrm{Q}}$-protein coupled. Their activation leads to the activation of phospholipase C (PLC), protein kinase C (PKC) and $\mathrm{Ca}^{2+}$ influx into the cells. The OXY and AVP projections are, therefore, "classical" neuromodulatory pathways and play an important role in memory, cognition, and emotional processing.

OXT and AVP may play an important role in stress response, anxiety, and depression. One study reported that OXT-knockout male and OXT-deficient female mice show increased anxiety. The anxiety level in OXT-deficient female mice was reserved by OXT treatment and enhanced by OXTR antagonist. Acute and chronic OXT had also an antidepressant-like effect in normal rats, as was measured using the forced swim test. Another study, however, reported that OXT knockout mice show similar anxiety level, 


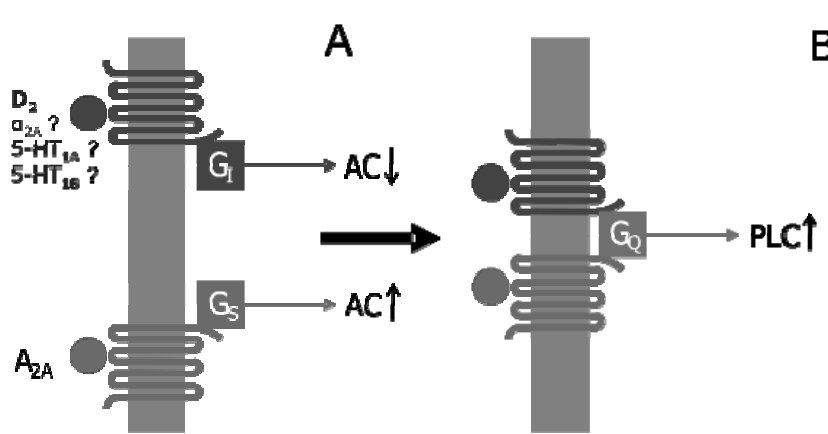

C

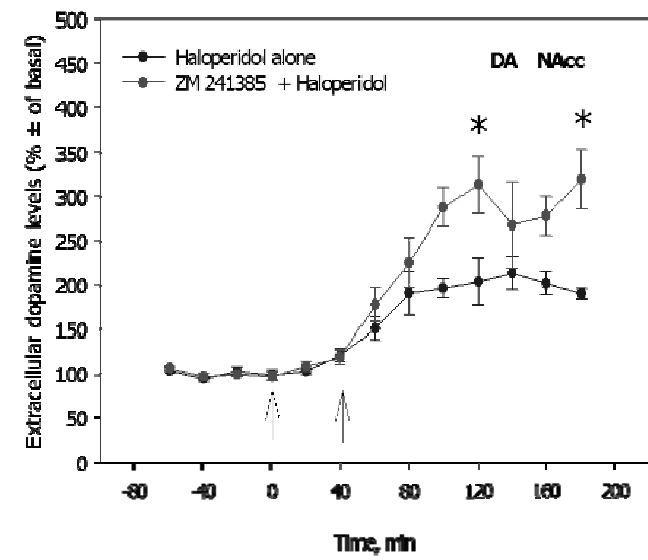

B

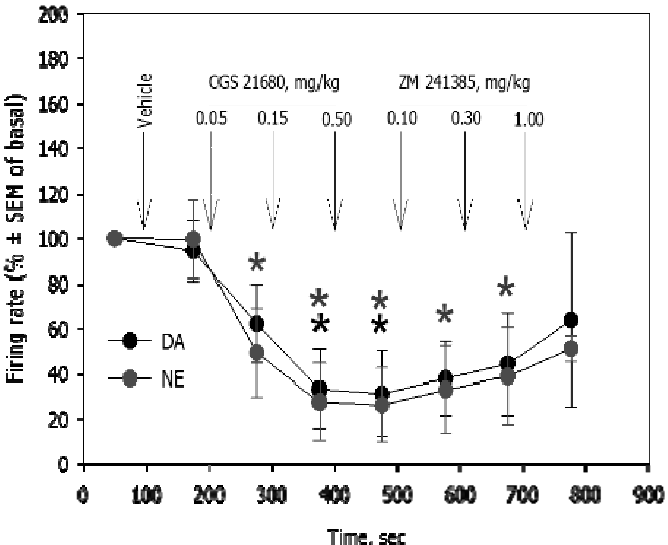

D

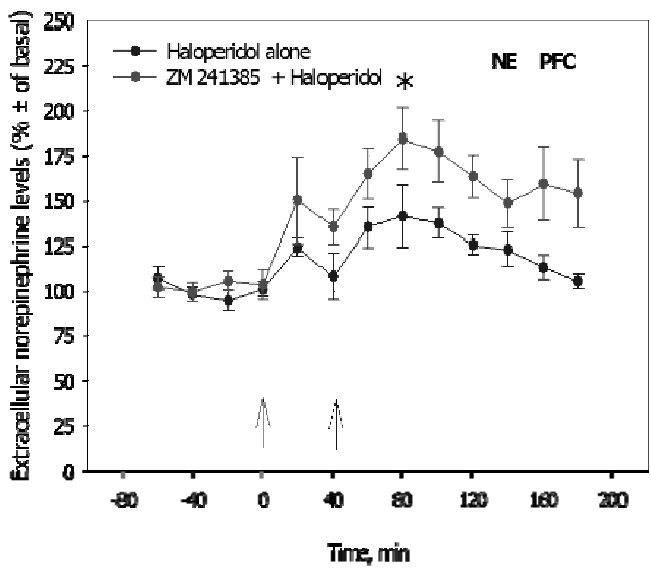

Fig. 5. Interactions between brain adenosine and monoamines. Adenosine-2A $\left(A_{2 A}\right)$ is a Gas-coupled receptor. Its activation stimulates the adenylyl cyclase (AC)-mediated cyclic adenosine monophosphate (cAMP)formation. Dopamine-2 $\left(\mathrm{D}_{2}\right)$, $\alpha_{2}$-adrenergic, and serotonin-1A/1B receptors $\left(5-\mathrm{HT}_{1 \mathrm{~A} / 1 \mathrm{~B}}\right)$ are $\mathrm{Ga}_{1}$-coupled. Its activation inhibits the adenylyl cyclase (AC)-mediated cyclic adenosine monophosphate (cAMP)formation.Adenosine-2A and dopamine-2 (and perhaps also $\alpha_{2}$-adrenergic and serotonin-1A/1B receptors) form a dimmer which is $\mathrm{Ga}_{\mathrm{Q}}$-coupled and stimulates phospholipase-C (PLC, A); CGS 21680, a selective adenosine-2A adenosine receptor agonist, and ZM 241385, a selective adenosine-2A adenosine receptor antagonist, oppositely regulate the firing activity of norepinephrine neurons of the locus coeruleus and dopamine neurons of the ventral tegmental area (B); ZM 241385 potentiates the haloperidol-induced increase in dopamine levels in the nucleus accumbens (NAcc, C) and norepinephrine levels in the prefrontal cortex (PFC, D)

but decreased aggression in comparison to wild type controls.

It was reported that Brattleboro AVP knockout rat demonstrate decreased anxiety and depressive-like behaviour following stress). Similarly, decreased anxiety was observed in $\mathrm{V}_{1 \mathrm{~A}}$ knockout mice, when the overexpression of this receptors leaded to increased anxiety. The $\mathrm{V}_{1 \mathrm{~B}}$ knockout mice did not demonstrate, however, any behavior changes related to the anxiety.

The neuropeptide $\beta$-endorphin are belongs to the family of endogenous opiates, or opioids. Similarly to monamines, OXT, and AVP, brain $\beta$-endorphin pathways demonstrate "classical" features of neuromodulatory system. The cell bodies of $\beta$-endorphin-secreting neurons are concentrated in the arcuate nucleus (ARN) of the hypothalamus and their axons innervate distant areas of the brain, such as periaqueductal area of the brain stem (where they activate other opioidsecreting neurons projecting into the spinal cord), hypothalamus, thalamus, prefrontal and cingulate cortex, and hippocampus. Similarly to other opoids, $\beta$-endorphin plays a central role in pain modulation. However, $\beta$-endorphin system is also fundamental in the mediation of motivation, reward, memory, and emotional processing $[21,40]$.

The CNS receptors to $\beta$-endorphin are divided into three subtypes: $\mu, \kappa$, and $\delta$. All these receptors are $G_{a \mathrm{al} /}$-protein coupled. The $\mu$-opioid receptors play a central role in pain modulation and euphoria; these receptors are also primarily responsible for the addictive properties of opiates. The $\kappa$-receptors have an analgesic effect similar to $\mu$-opioid receptors; however, their effect on 


\section{Клиническая и экспериментальная медицина}

reward feeling is opposite. The $\delta$-opioid receptors are out of special interest, since they play an important role in stress response, anxiety, and depression. Some agonists of these receptors are under preclinical and early clinical investigations as potential antidepressant and antiolytic drugs.

\section{Conclusion}

Interactions between different neurotransmitter systems, rather than an individual neurotransmitter, play a key role in pathophysiology and treatment of depression and related mood and anxiety disorder. Literally all existing antidepressant drugs act on monoamine systems of the brain (5-HT, NE, and DA). Although the lastgeneration antidepressants and mood stabilizers demonstrated higher safety and efficacy, their therapeutic potential remains limited. To achieve the better outcome in the treatment of depression, new medications and/or adjuncts to the existing ones should be developed. These new medications may target brain histamine and neuropeptide ( $\beta$-endorphin, oxytocin, and vasopressin) systems. The brain adenosine neurotransmission is also a potential target for the future antidepressant, mood stabilizing, and antipsychotic drugs. Since adenosine receptors are widely expressed over the body and mediate numerous crucial physiological functions, such as regulation of cardiac activity, these drugs may have severe side effects. The direct targeting of these drugs into the site of their action (e.g., PFC), using advanced neurosurgical and/or pharmaceutical means, can provide a solution to this difficulty.

\section{Acknowledgements}

This author of this work was supported via the Slovak Academy of Sciences Scholarship Program and Vega Grant 2/0024/15.

1. Airaksinen A.J., Jablonowski J.A., van der Mey M., Barbieret A.J. Radiosynthesis and Biodistribution of a Histamine H3 Receptor Antagonist 4-[3-(4-Piperidin-1-yl-But-1-Ynyl)[11C]Benzyl]-Morpholine: Evaluation of a Potential PET Ligand. Nucl Med Biol (England), 2006, vol. 33, pp. 801-810.

2. Airaksinen M.S., Panula P. The Histaminergic System in the Guinea Pig Central Nervous System: An Immunocytochemical Mapping Study Using an Antiserum Against Histamine. J Comp Neurol (United States), 1988, vol. 273, pp. 163-186.

3. Airaksinen M.S., Flugge G., Fuchs E., Panula P. Histaminergic System in the Tree Shrew
Brain. J Comp Neurol (United States), 1989, vol. 286, pp. 289-310.

4. Allmark M.G., Lu F.C., Carmichael E., Lavallee A. Some Pharmacological Observations on Isoniazid and Iproniazid. Ammerical Reviews in Tuberculosis, 1953, vol. 68, pp. 199-206.

5. Bakker R.A., Timmerman H., Leurs R. Histamine Receptors: Specific Ligands, Receptor Biochemistry, and Signal Transduction. Clin Allergy Immunol (United States). 2002, vol. 17, pp. 27-64.

6. Blier P., Montigny C. Serotoninergic But Not Noradrenergic Neurons in Rat Central Nervous System Adapt to Long-Term Treatment with Monoamine Oxidase Inhibitors. Neuroscience (England), 1985, vol. 16, pp. 949-955.

7. Blier P., Montigny C.D., Azzaro A.J. Modification of Serotonergic and Noradrenergic Neurotransmissions by Repeated Administration of Monoamine Oxidase Inhibitors: Electrophysiological Studies in the Rat Central Nervous System. J Pharmacol Exp Ther (United States), 1986, vol. 237, pp. 987-994.

8. Brown R.E., Stevens D.R., Haas H.L. The Physiology of Brain Histamine. Prog Neurobiol (England), 2001, vol. 63, pp. 637-672.

9. Connelly W.M., Shenton F.C., Lethbridge N. The Histamine H4 Receptor is Functionally Expressed on Neurons in the Mammalian CNS. Br J Pharmacol (England), 2009, vol. 157, pp. 55-63.

10. Corrodi H., Fuxe K. The Effect of Imipramine on Central Monoamine Neurons. J Pharm Pharmacol (England), 1968, vol. 20, pp. 230-231.

11. Cremers T.I., Rea K., Bosker F.J., Wikstromet H.V. Augmentation of SSRI Effects on Serotonin by 5-HT2C Antagonists: Mechanistic Studies. Neuropsychopharmacology (United States), 2007, vol. 32, pp. 1550-1557.

12. Cremers T.I., Giorgetti M., Bosker F.J., Hogg S., Arnt J. Inactivation of 5-HT(2C) Receptors Potentiates Consequences of Serotonin Reuptake Blockade. Neuropsychopharmacology (United States), 2004, vol. 29, pp. 1782-1789.

13. Delay J., Buisson J.F. Psychic Action of Isoniazid in the Treatment of Depressive States. Journal of Clinical and Experimental Psychopathololy, 1958, vol. 19. pp. 51-55.

14. Delgado P.L., Miller H.L., Salomon R.M. Tryptophan-Depletion Challenge in Depressed Patients Treated with Desipramine or Fluoxetine: Implications for the Role of Serotonin in the Mechanism of Antidepressant Action. Biol Psychiatry (United States), 1999, vol. 46, pp. 212-220. 
15. Dremencov E., Mansari M.E., Blier P. Distinct Electrophysiological Effect of Paliperidone and Risperidone on the Firing Activity of Rat Serotonin and Norepinephrine Neurons. Psychopharmacology (Germany), 2007, vol. 194, pp. 63-72.

16. Dremencov E. Aiming at New Targets for the Treatment of Affective Disorders: An introduction. Curr Drug Targets (Netherlands), 2009, vol. 10, pp. 1050-1051.

17. Dremencov E., Mansari M.E., Blier P. Effects of Sustained Serotonin Reuptake Inhibition on the Firing of Dopamine Neurons in the Rat Ventral Tegmental Area. J Psychiatry Neurosci (Canada), 2009, vol. 34, pp. 223-229.

18. Dremencov E., Mansari M.E,, Blier P. Brain Norepinephrine System as a Target for Antidepressant and Mood Stabilizing Medications. Curr Drug Targets (Netherlands), 2009, vol. 10, pp. 1061-1068.

19. Dremencov E., Mansari M.E., Blier P. Noradrenergic Augmentation of Escitalopram Response by Risperidone: Electrophysiologic Studies in the Rat Brain. Biol Psychiatry, 2007, vol. 61, pp. 671-678.

20. Dremencov E., Gur E., Lerer B., Newman M.E. Effects of Chronic Antidepressants and Electroconvulsive Shock on Serotonergic Neurotransmission in the Rat Hippocampus. Prog Neuropsychopharmacol Biol Psychiatry (England), 2003, vol. 27, pp. 729-739.

21. Dremencov E., Gur E., Lerer B., Newman M.E. Effects of Chronic Antidepressants and Electroconvulsive Shock on Serotonergic Neurotransmission in the Rat Hypothalamus. Prog Neuropsychopharmacol Biol Psychiatry (England), 2002, vol. 26, pp. 1029-1034.

22. Dremencov E., Gispan-Herman I., Rosenstein M., Mendelman A., Overstreet D.H., Zohar J., Yadid G. The Serotonin-Dopamine Interaction is Critical for Fast-Onset Action of Antidepressant Treatment: In Vivo Studies in an Animal Model of Depression. Prog Neuropsychopharmacol Biol Psychiatry (England), 2004, vol. 28, pp. 141-147.

23. Mansari E.M., Guiard B.P., Chernoloz O., Ghanbari R., Katz N., Blier P. Relevance of Norepinephrine-Dopamine Interactions in the Treatment of Major Depressive Disorder. CNS Neurosci Ther (England), 2010, vol. 16, p. 17.

24. Guiard B.P., Mansari M.E., Merali Z., Blier P. Functional Interaction Between Monoaminergic Neurons. Biol Psychiatry, 2007, vol. 61, pp. 125-125.
25. Guiard B.P., Mansari E.M., Merali Z., Blier P. Functional Interactions Between Dopamine, Serotonin and Norepinephrine Neurons: An In-Vivo Electrophysiological Study in Rats with Monoaminergic Lesions. Int $J$ Neuropsychopharmacol (England), 2008, vol. 11, pp. 625-639.

26. Haas H.L., Sergeeva O.A., Selbach O. Histamine in the Nervous System. Physiol Rev (United States), 2008, vol. 88, pp. 1183-1241.

27. Hew R.W., Hodgkinson C.R., Hill S.J. Characterization of Histamine H3-Receptors in Guinea-Pig Ileum with H3-Selective Ligands. $\mathrm{Br} J$ Pharmacol (England), 1990, vol. 101, pp. 621-624.

28. Iwase M., Homma I., Shioda S., Nakai Y. Histamine Immunoreactive Neurons in the Brain Stem of the Rabbit. Brain Res Bull (United States), 1993, vol. 32, pp. 267-272.

29. Kandel E.R., Schwartz J.H., Jessell T.M. Principles of Neural Science. New York: McGraw-Hill, Health Professions Division, 2000.

30. Kawahara Y., Kawahara H., Kaneko F., Tanaka M. Long-Term Administration of Citalopram Reduces Basal and Stress-Induced Extracellular Noradrenaline Levels in Rat Brain. Psychopharmacology (Germany), 2007, vol. 194, pp. 73-81.

31. Kennedy S.H. A Review of Antidepressant Treatments Today. Eur Neuropsychopharmacol (Netherlands), 2006, vol. 5, pp. 619-623.

32. Leurs R., Blandina P., Tedford C., Timmerman H. Therapeutic Potential of Histamine H3 Receptor Agonists and Antagonists. Trends Pharmacol Sci (England), 1998, vol. 19, pp. 177-183.

33. Lin J.S., Hou Y., Sakai K., Jouvet M. Histaminergic Descending Inputs to the Mesopontine Tegmentum and Their Role in the Control of Cortical Activation and Wakefulness in the Cat. J Neurosci (United States), 1996, vol. 16, pp. 1523-1537.

34. Martinez-Mir M.I., Pollard H., Moreau J., Arrang J.M., Ruat M., Traiffort E., Schwartz J.C., Palacios J.M. Three Histamine Receptors $(\mathrm{H} 1, \mathrm{H} 2$ and H3) Visualized in the Brain of Human and Non-Human Primates. Brain Res (Netherlands), 1990, vol. 526, pp. 322-327.

35. Moret C., Briley M. Effect of Antidepressant Drugs on Monoamine Synthesis in Brain in Vivo. Neuropharmacology (England), 1992, vol. 31, pp. 679-684.

36. Panula P., Pirvola U., Auvinen S., Airaksinen M.S. Histamine-Immunoreactive Nerve 


\title{
Клиническая и экспериментальная медицина
}

Fibers in the Rat Brain. Neuroscience (England), 1989, vol. 28, pp. 585-610.

37. Pollard H., Moreau J., Arrang J.M., Schwartz J.C. A Detailed Autoradiographic Mapping of Histamine H3 Receptors in Rat Brain Areas. Neuroscience (England), 1993, vol. 52, pp. 169-189.

38. Ravindran L., Kennedy S.H. Are Antidepressants as Effective as Claimed? Yes, But... Can J Psychiatry (Canada), 2007, vol. 52, pp. 98-99.

39. Robot M. Isoniazid and Its Psychological Effects. Annual Medical Psychology (Paris), 1954, vol. 112, pp. 161-183.

40. Salzer H.M., Lurie M.L. Depressive States Treated with Isonicotinyl Hydrazide (Isoniazid); A Follow-Up Study. Ohio Medicine, 1955, vol. 51, pp. 437-441.

41. Schlicker E., Malinowska B., Kathmann M., Gothert M. Modulation of Neurotransmitter Release Via Histamine H3 Heterore- ceptors. Fundam Clin Pharmacol (France), 1994, vol. 8, pp. 128-137.

42. Schlicker E., Kathmann M., Detzner M., Exner H.J., Gothert M. H3 Receptor-Mediated Inhibition of Noradrenaline Release: An Investigation into the Involvement of $\mathrm{Ca} 2+$ and $\mathrm{K}+$ Ions, G Protein and Adenylate Cyclase. Naunyn Schmiedebergs Arch Pharmacol (Germany), 1994, vol. 350, pp. 34-41.

43. Vanhala A., Yamatodani A., Panula P. Distribution of Histamine-, 5-Hydroxytryptamine-, and Tyrosine Hydroxylase-Immunoreactive Neurons and Nerve Fibers in Developing Rat Brain. J Comp Neurol (United States), 1994, vol. 347, pp. 101-114.

44. Vollinga R.C., Koning J.P., Jansen F.P., Leurs R., Menge W.M., Timmerman H. A New Potent and Selective Histamine H3 Receptor Agonist, 4-(1H-Imidazol-4-Ylmethyl) Piperidine. $J$ Med Chem (United States), 1994, vol. 37, pp. 332-333.

Received 15 May 2016

Удк 616.831-001

DOI: $10.14529 / \mathrm{hsm} 160202$

\section{РОЛЬ ВЗАИМОДЕЙСТВИЙ МЕЖДУ НЕЙРОМЕДИАТОРАМИ ГОЛОВНОГО МОЗГА В ПАТОФИЗИОЛОГИИ И ЛЕЧЕНИИ АФФЕКТИВНЫХ РАССТРОЙСТВ}

\section{Э. Дременков}

\author{
Институт молекулярной фризиологии и генетики, Словацкая академия наук, \\ Братислава, Словакия; \\ Институт экспериментальной эндокринологии, Центр биомедицинских исследований, \\ Словацкая академия наук, Братислава, Словакия; \\ Консалтинговая компания Neuroken Consulting, Гронинген, Нидерланды
}

\begin{abstract}
Целью настоящей обзорной статьи является обобщение известных на текущий момент данных о взаимодействиях между нейромедиаторами головного мозга и их роли в патофизиологии и лечении депрессии. Введение. Нейромедиаторы головного мозга представляют собой биологические молекулы, ответственные за передачу сигнала между нейронами. Нейромедиаторы головного мозга у млекопитающих относятся к разным типам биологических молекул, включающим аминокислоты (глутамат и $\gamma$-аминомасляную кислоту, или ГАМК), моноамины (серотонин (5-НТ), норадреналин (НА), допамин (Д), а также гистамин $(\Gamma)$ ), нейропептиды ( $\beta$-эндорфин, нейрокинин, вазопрессин и окситоцин) и нуклеотиды (аденозин). Материалы и методы. Автор анализирует научные работы, изданные в период с 1953 по 2014 г. и посвященные нейромедиаторам и их функциям в регуляции настроения. Статья посвящена в первую очередь оценке данных о механизмах взаимодействия различных нейромедиаторов и их роли в развитии и лечении отдельных психических расстройств. Результаты. Согласно литературным источникам, нейромедиаторы, нередко относящиеся к разным типам
\end{abstract}


биологических молекул, взаимодействуют на поведенческом, функциональном, системном и молекулярном уровнях. Эти взаимодействия играют важную роль в патофизиологии заболеваний головного мозга, в частности, депрессии и стрессовых и тревожных расстройств. Заключение. Практически все существующие антидепрессанты воздействуют на моноаминовые системы головного мозга (5-НТ, НЭ и Д). Невзирая на то, что антидепрессанты и стабилизаторы настроения последнего поколения обладают высокой степенью надежности и эффективности, их терапевтический потенциал пока ограничен. Большой интерес представляет разработка антидепрессантов, стабилизаторов настроения и нейролептиков, воздействующих на нейропередачу с участием аденозина. Однако такие препараты могут иметь серьезные побочные эффекты, например, негативно влиять на сердечную деятельность. Для разрешения существующих трудностей необходимо проведение дальнейших научных и клинических исследований.

Ключевые слова: серотонин (5-HT), норадреналин, допамин, глутамат, ГАМК, нейропептиды, гипоталамус, гиппокамп, потенцииалзависимые кальциевые каналь.

Дременков Элияху, $\mathrm{PhD}$, Институт молекулярной физиологии и генетики, Словацкая академия наук; Институт экспериментальной эндокринологии, Центр биомедицинских исследований, Словацкая академия наук, Братислава, Словакия; Консалтинговая компания Neuroken Consulting, Гронинген, Нидерланды, eliyahu.dremencov@savba.sk.

Поступила в редакцию 15 мая 2016 2.

\section{ОБРАЗЕЦ ЦИТИРОВАНИЯ}

Dremencov, E. The role of interactions between brain neurotransmitters in pathophysiology and treatment of affective disorders / E. Dremencov // Человек. Спорт. Медицина. - 2016. - Т. 16, № 2. - C. 18-29. DOI: $10.14529 / \mathrm{hsm} 160202$

\section{FOR CITATION}

Dremencov E. The Role of Interactions Between Brain Neurotransmitters in Pathophysiology and Treatment of Affective Disorders. Human. Sport. Medicine, 2016, vol. 16, no. 2, pp. 18-29. DOI: 10.14529/hsm160202 